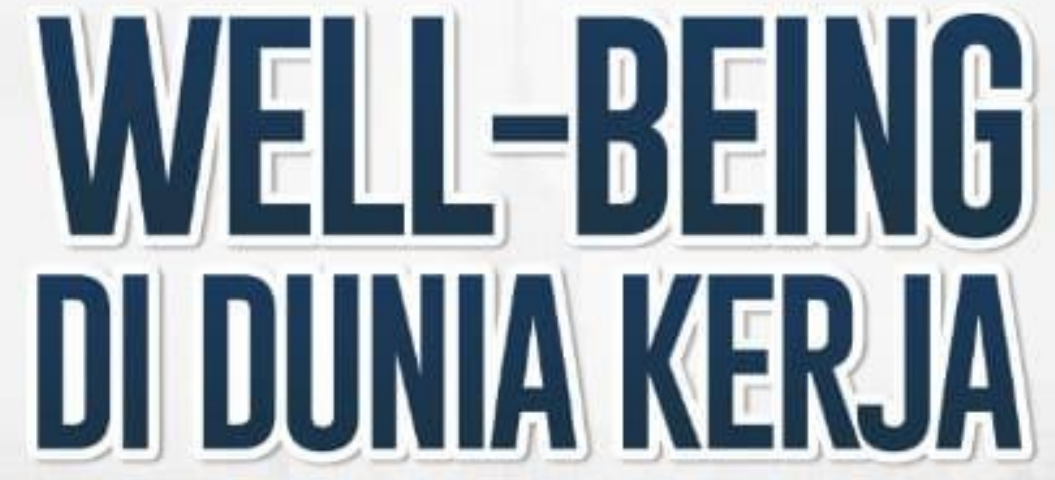

Well-being dalam dunia kerja menjadi factor yang penting agar perusahaan dapat mencapai bahkan melampuai target yang diharapkan. Buku yang hadir di hadapan pembaca ini diharapkan dapat menjadi referensi untuk kajian sejenis di bidang psikologi positif yang terkait dengan aspek-aspek positif yang ada di dalam dan di luar individu sesuai dengan budaya dan individu Indonesia. Buku ini juga diharapkan dapat memberikan pemahaman baru tentang peranan pengembangan karir, job security dan kepuasan kerja untuk mencapai wellbeing dan pentingnya kajian tentang well-being di dunia kerja (work related well-being).

Tidak hanya pada aspek teoritis, namun juga menyajikan data empiris sehingga diharapkan dapat membantu organisasi untuk bisa melakukan usahausaha menciptakan well being kepada para karyawannya. Organisasi dapat memberikan perhatian pada bagaimana memberikan kepuasan kerja karyawannya melalui upaya memberikan perhatian pada upaya pengembangan karir yang jelas dan memberikan job security kepada karyawannya. Kemampuan tersebut dapat membantu organisasi mempunyai nilai tambah untuk dapat bersaing di dunia bisnis di masa yang akan datang. Akhirnya selamat membaca dan semoga ada manfaatnya.
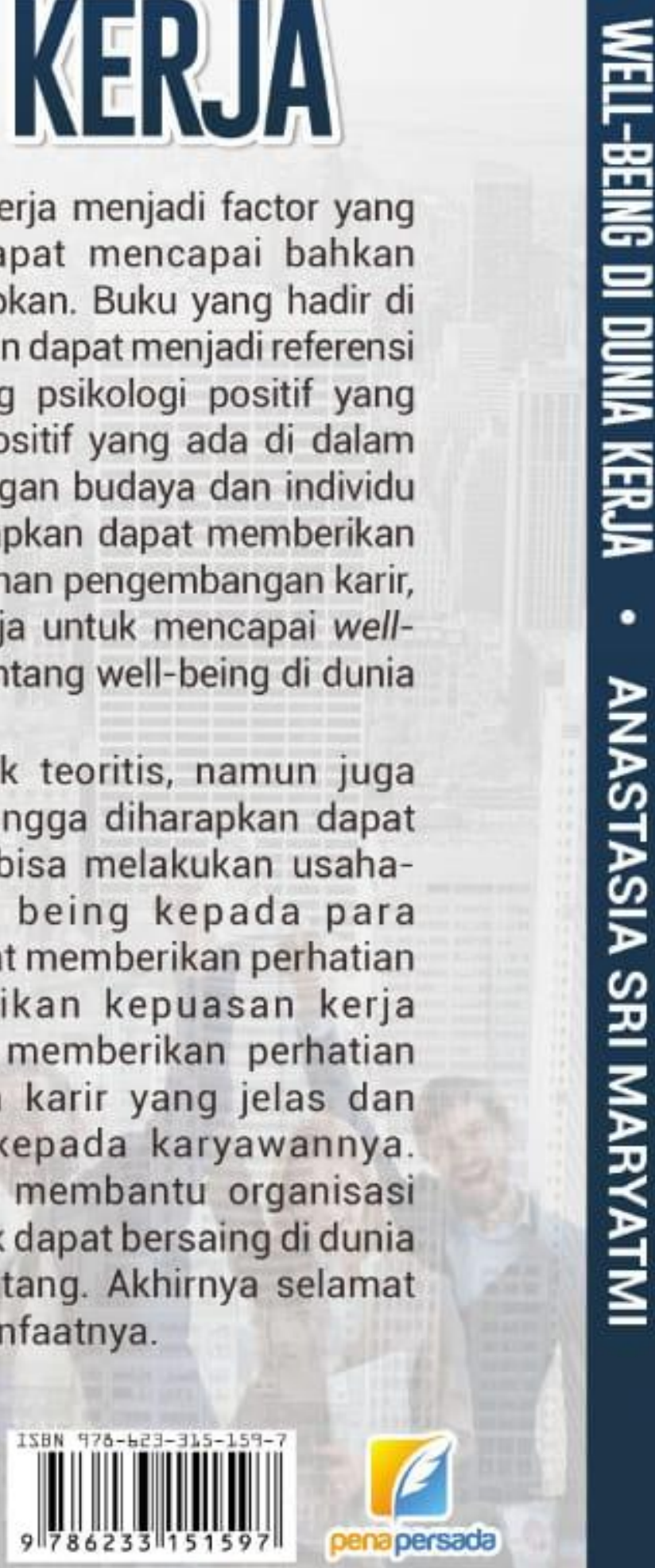

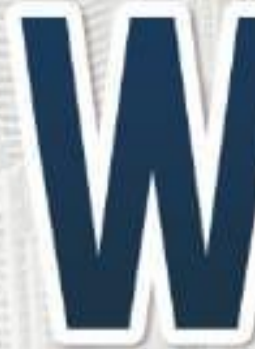

ANASTASIA SRI MARYATMI
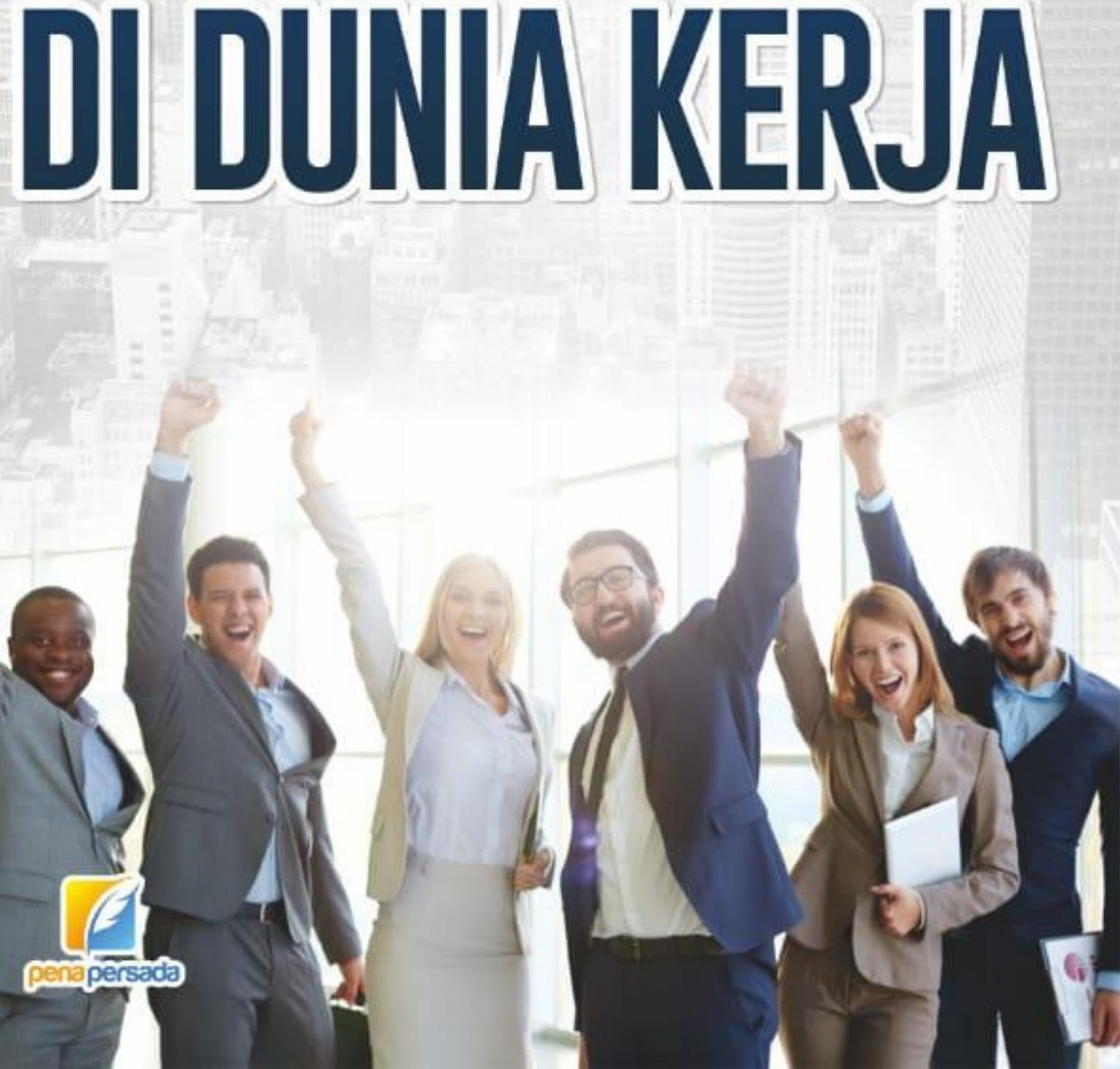


\section{WELL-BEING DI DUNIA KERJA}

ANASTASIA SRI MARYATMI

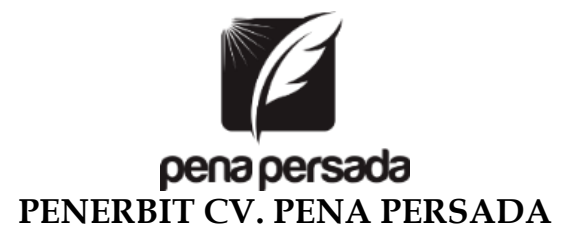




\title{
WELL-BEING DI DUNIA KERJA
}

\author{
Penulis: \\ Anastasia Sri Maryatmi \\ ISBN : 978-623-315-159-7 \\ Editor: \\ Tri Hidayati \\ Design Cover : \\ Retnani Nur Briliant \\ Layout : \\ Hasnah Aulia \\ Penerbit CV. Pena Persada \\ Redaksi : \\ Jawa Tengah \\ Email : penerbit.penapersada@gmail.com \\ Anggota IKAPI \\ All right reserved \\ Cetakan pertama : 2021
}

Jl. Gerilya No. 292 Purwokerto Selatan, Kab. Banyumas

Website : penapersada.com Phone : (0281) 7771388

Hak Cipta dilindungi oleh undang-undang. Dilarang memperbanyak karya tulis ini dalam bentuk apapun tanpa izin penerbit 


\section{KATA PENGANTAR}

Puji syukur saya panjatkan kepada Tuhan Yang Maha Esa, karena atas berkat dan rahmat-Nya, saya dapat menyelesaikan buku ini. Saya menyadari bahwa tanpa bantuan dan bimbingan dari berbagai pihak sangatlah sulit bagi saya untuk menyelesaikan karya ini. Oleh karena itu, saya mengucapkan banyak terima kasih pada semua pihak yang telah membantu penyusunan buku ini. Sehingga buku ini bisa hadir di hadapan pembaca.

Buku ini diharapkan dapat menjadi referensi untuk kajian sejenis di bidang psikologi positif yang terkait dengan aspek-aspek positif yang ada di dalam dan di luar individu sesuai dengan budaya dan individu Indonesia. Selain hal tersebut juga diharapkan dapat memberikan pemahaman baru tentang peranan pengembangan karir, job security dan kepuasan kerja untuk mencapai well-being dan pentingnya kajian tentang well-being di dunia kerja (work related well-being).

Buku ini diharapkan dapat membantu organisasi untuk bisa melakukan usaha-usaha menciptakan well being kepada para karyawannya, setidaknya lewat variable-variabel yang diteliti dalam penelitian ini. Organisasi dapat memberikan perhatian pada bagaimana memberikan kepuasan kerja karyawannya melalui upaya memberikan perhatian pada upaya pengembangan karir yang jelas dan memberikan job security kepada karyawannya. Kemampuan tersebut dapat membantu organisasi mempunyai nilai tambah untuk dapat bersaing di dunia bisnis di masa datang.

Penulis menyadari bahwa buku ini masih jauh dari kesempurnaan. Oleh karena itu kritik dan saran yang membangun sangat dibutuhkan guna penyempurnaan buku ini. Akhir kata saya berharap Tuhan Yang Maha Esa berkenan membalas segala kebaikan semua pihak yang telah membantu. 


\section{DAFTAR ISI}

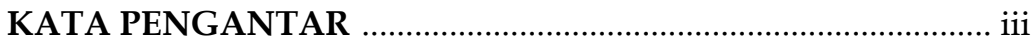

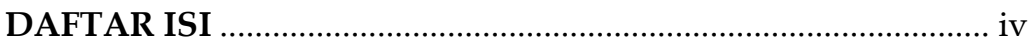

BAB I PENDAHULUAN

A. Persoalan Kepuasan Kerja .................................................... 1

B. Persoalan Well Being.............................................................. 3

C. Persoalan Pengembangan Karir ............................................ 6

BAB II TEORI TENTANG WELL-BEING DAN JOB SECURITY

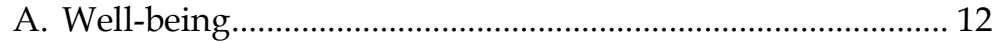

1. Pengertian Well-being .......................................................... 12

2. Aspek-aspek Well-being ..................................................... 14

3. Faktor-faktor yang Mempengaruhi Well-being.............. 17

B. Job Security …....................................................................... 19

1. Pengertian Job Security …………………….................... 19

2. Aspek-aspek Job Security ................................................. 21

BAB III TEORI TENTANG KEPUASAN KERJA DAN PENGEMBANGAN KARIR

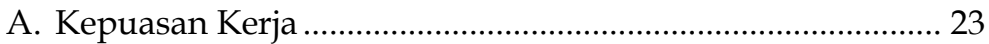

1. Pengertian Kepuasan Kerja ……………………………..... 23

2. Aspek-aspek Kepuasan Kerja............................................. 25

3. Faktor-faktor Yang Mempengaruhi Kepuasan Kerja..... 28

B. Pengembangan Karir .......................................................... 34

1. Pengertian Pengembangan Karir....................................... 34

2. Aspek-aspek Pengembangan Karir ................................. 37

BAB IV ANALISA TENTANG WELL-BEING, KEPUASAN KERJA, PENGEMBANGAN KARIR DAN JOB SECURITY

A. Uji Pengujian 2nd Order Confirmatory Factor Analysis .... 41

1. Uji confirmatory factor analysis variabel Well-being .... 41

2. Uji confirmatory factor analysis variabel Kepuasan

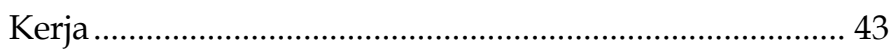

3. Uji confirmatory factor analysis variabel Pengembangan Karir ......................................................... 45

4. Uji confirmatory factor analysis variabel job security ... 47

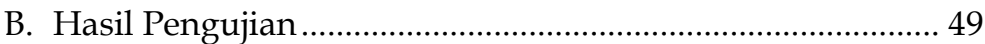

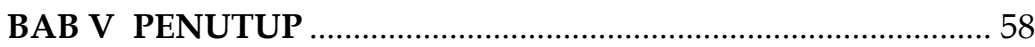

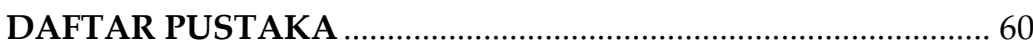




\section{BAB I \\ PENDAHULUAN}

\section{A. Persoalan Kepuasan Kerja}

Dewasa ini, perusahaan dihadapkan dengan semakin kompetitif dan cepatnya perubahan dalam lingkungan bisnis. Globalisasi dan kemajuan pesat di bidang komunikasi dan teknologi informasi dalam dua puluh tahun terakhir telah menyebabkan peningkatan substansial dalam persaingan antar perusahaan. Di sisi lain, para konsumen juga mengalami perubahan dalam perilaku konsumsinya. Konsumen menuntut kualitas yang lebih tinggi, kehandalan, keanekaragaman produk, kecepatan, dan kemudahan dari barang dan jasa yang dibeli. Konsumen secara langsung maupun tidak langsung akhirnya mendorong perusahaan untuk berkinerja dengan standard baru karena konsumen memiliki lebih banyak pilihan barang dan jasa serta mengubah kebutuhan dan keinginannya dengan cepat.

Pertumbuhan yang melambat dan melonjaknya biaya produksi akibat dari krisis ekonomi global akhir-akhir ini telah mendorong banyak perusahaan untuk bersaing memotong harga dan biaya. Menyempurnakan proses bisnis, memangkas struktur manajemen dan merampingkan jumlah karyawan telah menjadi praktek jamak (Luthans et al., 2008). Selain itu, tren tenaga kerja juga menjadi berubah. Karyawan diharapkan untuk mempertahankan kualitas kerja yang tinggi dengan meningkatkan efisiensi dan produktivitas di tengah-tengah situasi yang penuh dengan ketidakpastian dan perubahan. Sehingga karyawan menghadapi peningkatan tekanan untuk melakukan lebih banyak pekerjaan dan bekerja dengan tambahan waktu yang lebih banyak.

Hampir seluruh manusia dewasa yang bekerja menghabiskan sepertiga hingga setengah waktunya untuk bekerja. Kerja adalah landasan dan pusat dari segala sesuatu 
yang terkait dengan kualitas hidup seseorang, memberikan "sense of structure", status, dan tujuan (Salkever, 2000). Dengan demikian, pekerjaan adalah lebih dari sekedar tempat untuk mendapatkan hidup, tetapi juga menjadi tempat karyawan menemukan makna, stabilitas komunitas dan identitas pribadi (Cartwright \& Homes, 2006).

Hubungan pekerjaan telah berubah secara drastis dalam beberapa dekade terakhir ini. Berubah tidak saja pada jenis pekerjaan yang dilakukan karyawan tetapi juga pada kapan karyawan bekerja dan seberapa banyak yang karyawan lakukan. Bagi kebanyakan karyawan sekarang ini, meningkatnya pekerjaan melibatkan pekerjaan paruh waktu, pekerjaan kontrak dan karir ganda. Selanjutnya, tidak saja semakin banyak pekerja yang memegang pekerjaan ganda, tetapi juga terjadi peningkatan yang paralel dalam jumlah waktu lembur yang dilakukan oleh karyawan untuk menyelesaikan pekerjaannya (Turner, Barling \& Zacharatos, 2005).

Keadaan ini, menurut Turner, Barling \& Zacharatos (2005) akan membuat pekerja menghadapi penurunan pilihan dan kendali, yang pada gilirannya, membuat banyak pekerja tidak hanya kehilangan kontrol pada waktu kerjanya tetapi juga akan mengakibatkan hilangnya "sense of job" dan rasa aman dalam bekerja; apabila keadaan ini dibiarkan tanpa perhatian dari manajemen, maka akan mempengaruhi tingkat well being pekerja.

Menurut Ryff dan Keyes (1995) well being merupakan istilah yang digunakan untuk menggambarkan kesejahteraan psikologis individu berdasarkan pemenuhan kriteria fungsi psikologi positif. Kesejahteraan psikologis adalah suatu kondisi psikologis individu yang sehat ditandai dengan berfungsinya aspek-aspek psikologis positif dalam prosesnya mencapai aktualisasi diri. Menurut Ryff (1989) gambaran tentang karakteristik orang yang memiliki kesejahteraan psikologis merujuk pada pandangan Rogers tentang individu yang berfungsi penuh (fully-functioning person), pandangan Maslow 
tentang aktualisasi diri (self actualization), pandangan Jung tentang individuasi dan konsep Allport tentang kematangan. Juga sesuai dengan konsep Erikson dalam menggambarkan individu yang mencapai integrasi dibanding putus asa, konsep Neugarten tentang kepuasan hidup, serta kriteria positif tentang orang yang bermental sehat yang dikemukakan Johada. Menurut Ryff dan Keyes (1995), fondasi untuk memperoleh kesejahteraan psikologis adalah individu yang secara psikologis dapat berfungsi secara positif (positive psycholigical functioning).

\section{B. Persoalan Well Being}

Warr (1999) dalam pendekatannya dalam pengukuran tentang well being, mencirikan well being secara umum sebagai suatu "keadaan yang aktif (active state)" yang berisikan afek positif dan gairah yang tinggi (high arousal). Dalam konteks pekerjaan secara lebih spesifik, Warr memberi perhatian pada variabel kepuasan kerja, keterlibatan kerja dan komitmen organisasi (yang merefleksikan bagaimana pekerja merasakan tentang pekerjaannya) sebagai sedikit dari banyak variabel yang dapat diukur dalam hubungannya dengan job related well being.

Meskipun penelitian pada kepuasan kerja sangat luas, namun menurut Page (2005) masih ditemukan adanya beberapa keterbatasan. Pertama adalah kurangnya pemahaman sekitar sifat-sifat kepuasan kerja itu sendiri. Sebagai contoh apakah kepuasan kerja tersebut murni konstrak kognitif atau termasuk komponen afektif? Aspek-aspek kerja apa saja yang diperhatikan oleh individu ketika menilai tingkat kepuasan kerjanya? Seberapa stabilkah kepuasan kerja individu sepanjang waktu tertentu?

Page (2005) berpendapat bahwa cara untuk memahami keterbatasan tersebut adalah dengan memahami suatu cabang dari well-being yang memperhatikan tentang bagaimana perasaan karyawan di tempat kerja yang disebut work place well-being (well-being di tempat kerja). Meskipun well-being 
biasanya dipandang sebagai suatu penilaian yang menyeluruh tentang kepuasan dalam hidup, juga dapat dikonseptualisasikan sebagai suatu penjumlahan kepuasan dalam beberapa aspek kehidupan (seperti dalam pekerjaan, hubungan dengan individu lain dan kesehatan).

Meskipun kepuasan kerja biasanya tidak dibicarakan dalam kerangka kerja well-being, namun dapat diasumsikan keduanya terkait karena tingginya proporsi waktu yang digunakan individu di tempat kerja. Beberapa spekulasi muncul seputar keterkaitan kedua konstrak ini, beberapa peneliti percaya bahwa kepuasan hidup menjadi penyebab (determinant) dari kepuasan kerja dan yang lainnya percaya bahwa kepuasan kerja adalah salah satu penyebab bagi kepuasan hidup secara keseluruhan (Rode, 2004). Tanpa memperhatikan urutan sebab akibatnya, hasil penelitian mengarah pada kesimpulan bahwa kepuasan kerja dengan well being berhubungan secara positif, meskipun hubungannya tidak terlalu kuat (Rode, 2004). Sebagai contoh, meta analisis yang dilakukan oleh Rice, Near and Hunt (1980) mengkaji bukti empirik dari 23 hasil kajian tentang hubungan antara kepuasan hidup dan kepuasan kerja. Ketiganya menemukan rata-rata korelasi sebesar 0.3, yang mengindikasikan bahwa kedua konstrak hanya memberi sumbangan sebesar 9\% dari varian. Rata-rata korelasi ini juga ditemui pada dua kajian meta analisis lainnya (Judge \& Watanabe, 1993; Rode, 2004 ). Beberapa hasil penelitian lain sebelumnya juga memberikan hasil yang tidak konsisten. Terdapat penelitian yang mendukung hubungan antara kepuasan kerja dengan well being, seperti Judge dan Hulin (1990, 1991), Judge et al. (2001) dan Page (2005). Sementara di lain pihak terdapat penelitian yang mendukung hubungan antara well being dan kepuasan kerja, seperti Diener et al. (1999) dan Judge dan Locke (1992).

Hasil kajian di atas juga didukung oleh penelitian Judge et al. (2001) yang menunjukkan bahwa kepuasan kerja merupakan salah satu prediktor bagi munculnya well-being. Hal tersebut diperkuat oleh pendapat Bakker dan Oerlemans (2010) 
yang mengatakan bahwa kepuasan kerja merupakan bentuk subjective well-being di tempat kerja yang paling sering dijadikan sebagai bahan kajian.

Korelasi yang rendah tersebut mungkin disebabkan oleh, di satu sisi, bila kepuasan kerja adalah hanya suatu komponen dari kepuasan hidup, rendahnya hubungan merupakan gambaran sesungguhnya dari hubungan keduanya. Bagaimanapun juga, di samping pekerjaan ada banyak faktor dalam kehidupan individu yang berkontribusi dalam well-being individu (seperti misalnya hubungan dengan individu lain, aktivitas sosial, aktivitas rekreatif dan sebagainya).

Sejumlah peneliti, yang memberikan alternatif pandangan tentang kepuasan kerja telah memberikan apresiasi terhadap pernyataan tersebut. Beberapa penulis menjabarkan kepuasan kerja sebagai suatu keadaan dalam pikiran dan memberikan interpretasi yang berbeda. Sebagai contoh, Gregson (1987) mendefinisikan kepuasan kerja sebagai suatu keadaan emosional positif yang berasal dari penilaian individu atas pekerjaan atau pengalamannya. Chay dan Bruvold (2003) mendefinisikan kepuasan kerja sebagaia respon afektif individu terhadap aspek-aspek tertentu dalam pekerjaan.

Wiener, 1982 (dalam Jepsen\&Sheu,2003) mengatakan kepuasan kerja adalah suatu bentuk sikap terhadap kondisikondisi yang berkaitan dengan pekerjaan, baik segi maupun aspeknya. Jelasnya, para teoris dan praktisi menerima anggapan bahwa setiap individu pastilah mencari kepuasan di dalam pekerjaannya. Menurut Jepsen dan Sheu (2003), manakala individu terikat dalam pekerjaan yang sesuai dengan pilihan karirnya, biasanya akan mengalami kepuasan kerja.

Terkait dengan pendapat Jepsen dan Sheu (2003) di atas, pilihan karir dalam pekerjaan yang sesuai juga meningkatkan kepuasan kerja. Organisasi-organisasi yang menjalankan program manajemen karir dengan baik umumnya adalah organisasi yang dapat meningkatkan kepuasan kerja karyawannya (Lee 2000). Pengembangan karir tidak saja menjadi kepentingan karyawan, tetapi juga menjadi perhatian 
organisasi. Pengembangan karir dapat dijalankan oleh organisasi melalui program manajemen karir.

\section{Persoalan Pengembangan Karir}

Dalam dunia bisnis global, di mana perubahan secara terus menerus berlangsung, kesesuaian individu dengan pilihan karirnya dapat membantu mengatasi tekanan-tekanan akibat perubahan tersebut. Perubahan yang terus menerus pada tataran organisasi tersebut membuat pentingnya pengelolaan sumber daya manusia di tempat kerja, terutama dalam perencanaan dan pengelolaan karir individu (Baruch, 2004). Karyawan adalah sumber daya yang paling bernilai dalam organisasi dewasa ini dan memberinya karir jangka panjang yang stabil adalah suatu situasi yang saling menguntungkan baik bagi organisasi maupun bagi karyawan.

Hall et al. (1986) telah mendefinisikan karir sebagai proses sepanjang hayat yang terbentuk dari rangkaian aktivitas yang terus menerus dan berhubungan dengan sikap atau perilaku dalam kehidupan kerja individu. Karir dapat juga dipandang sebagai suatu pola yang kerja yang berhubungan dengan pengalaman, seperti posisi pekerjaan, pekerjaan atau aktivitas, pengambilan keputusan dalam pekerjaan, dan interpretasi subjektif atas peristiwa-peristiwa yang terjadi dalam bekerja seperti aspirasi kerja, pengharapan, nilai-nilai, kebutuhan-kebutuhan dan perasaan-perasaan tentang pengalaman kerja tertentu sepanjang kehidupan individu (Greenhaus, et al. 2000). Jelasnya, suatu karir bukanlah sematamata suatu pekerjaan (job), tetapi juga menyangkut suatu proses, sikap, perilaku dan situasi dalam kehidupan kerja individu untuk mencapai tujuan karir. Baruch (2004) mengatakan bahwa karir adalah hak setiap individu, tetapi bagi organisasi, karir karyawan harus direncanakan dan dikelola dengan baik, demi mencapai manfaat maksimal baik bagi organisasi maupun karyawan. 
Pengembangan karir adalah pengembangan karyawan yang bermanfaat bagi organisasi dan individu serta merupakan suatu proses yang komplek. Teori-teori seputar kompleksnya proses pengembangan karir mulai muncul tahun 1950 dengan beberapa tokoh seperti Ginzberg, Super, Roe, Holland dan Tiedeman (Herr \& Shahnasarian, 2001). Selama 50 tahun terakhir, teori dan aplikasi pengembangan karir telah diciptakan, diuji dan didefinisikan (Herr, 2001). Leibowitz, Farren dan Kaye (1986) berpendapat bahwa pengembangan organisasi melibatkan suatu upaya yang terorganisasi, formal, terencana guna mencapai kesesuaian antara kebutuhan karir individu dengan kebutuhan organisasi.

Herr (2001) berpendapat bahwa fenomena tersebut terjadi akibat dari dinamisnya lingkungan bisnis global yang mengakibatkan meningkatnya pilihan karir individu. Lebih lanjut, Herr menggarisbawahi bahwa bagaimana membuat intervensi program perencanaan karir dengan sebaik-baiknya yang berpengaruh terhadap efektivitas organisasi.

Menurut McDaniels dan Gysbers (1992), pengembangan karir adalah konstelasi total faktor-faktor psikologis, sosiologis, pendidikan, fisik, ekonomi dan kesempatan yang secara bersama-sama membentuk karir individu sepanjang hidupnya. Greenhaus et al. (2000) mengatakan bahwa pengembangan karir adalah suatu proses yang terus-menerus yang dijalani oleh individu melalui tahapan-tahapan, di mana pada setiap tahapan berisikan masalah, tema dan tugas-tugas yang unik.

Perencanaan dan pengembangan karir yang mengarah kepada keefektifan organisasi sangat bergantung kepada kemampuan organisasi untuk mengubah karyawan dari pola pikir tradisional di mana karyawan hanya dapat berharap akan pengembangan karirnya ke tanggung jawab yag lebih besar terhadap pertumbuhan dan pengembangan karir karyawan sendiri (Martin, Romero, Valle \& Dolan 2001). Desain sistem pengembangan karir yang baik memungkinkan organisasi mendapatkan karyawan yang berbakat melalui penempatan dan promosi dengan menyepadankan ketrampilan, 
pengalaman dan aspirasi individu dengan kebutuhan organisasi. Sistem pengembangan karir memungkinkan organisasi membuat kebijakan seputar kompensasi dan perencanaan suksesi untuk menarik, mempertahankan dan memotivasi karyawan, yang dapat menghasilkan tenaga kerja yang lebih terikat dan produktif (Thite, 2001; Kapel \& Shepherd, 2004; Kaye 2005). Lebih jauh, pengembangan karir haruslah sebuah sistem berkelanjutan yang terkait dengan struktur sumber daya manusia (Leibowitz, et al., 1988).

Perusahaan yang menggunakan program pengembangan karir menimbulkan kepuasan karyawan yang lebih tinggi dan tingkat turnover yang rendah (Wagner, 2000).

Ketika karyawan merasa dirinya membantu perusahaan mencapai tujuan, karyawan merasa senang dan berkeinginan untuk tetap bertahan meneruskan kontribusinya (Logan, 2000). Begitu juga pendapat Moses (2000), karyawan merasa senang karena pekerjaannya berguna dan aktivitas kerjanya berarti bagi perusahaan. Karyawan yang termasuk berkinerja baik biasanya tidak akan meninggalkan suatu pekerjaan karena uang. Hal ini sering terjadi dikarenakan pekerjaannya tidak sesuai dengan tujuan dan segala sesuatu yang membuatnya bahagia (Melymuka, 2000). Meskipun gaji dan tunjangan memainkan peranan penting dalam merekrut dan mempertahankan karyawan, karyawan juga mencari kesempatan untuk mempelajari sesuatu yang baru, tantangan akan tanggung jawab baru dan prospek pengembangan diri dan profesional (Wagner, 2000). Menurut Nunn (2000), jika memuaskan, kebutuhan instrinsik membantu membangun rasa percaya, loyalitas dan kepuasan karyawan.

Thomas et al., (2006) mengatakan bahwa memuaskan karyawan juga dapat dilakukan dengan memberikan job security. Job security disebut sebagai salah satu variabel yang dapat menciptakan kepuasan kerja. Job security sering dikonsepkan sebagai jaminan terhadap kelangsungan suatu pekerjaan yang dimiliki individu (De Witte \& Nashwall, 2003). 
Dapat dikatakan bahwa karyawan yang merasakan adanya jaminan bagi kelangsungan pekerjaannya, akan merasakan kepuasan kerja yang lebih dibanding karyawan merasakan sebaliknya. Penelitian Ashford, Lee dan Bobko (1989) memperlihatkan bahwa karyawan yang merasakan rendahnya rasa aman terhadap kekaryawanannya di masa datang lebih merasa tidak puas dibanding dengan karyawan yang merasa situasi pekerjaan di masa datang lebih dianggap aman atau terjamin.

Bertitik tolak dari uraian tersebut, maka menarik untuk dilakukan kajian secara ilmiah mengenai pengaruh variabelvariabel kepuasan kerja, pengembangan karir dan job security terhadap well being pada karyawan PT X. Pilihan fokus kajian ini dilatarbelakangi oleh kondisi faktual bahwa karyawan PT X merasakan adanya kepuasan dan kebahagiaan setelah bekerja beberapa tahun di perusahaan ini. Hasil pra-studi yang penulis lakukan dengan mewawancarai beberapa karyawan PT X dari berbagai bagian menunjukkan bahwa para karyawan tersebut merasa bahagia menjadi bagian dari perusahaan ini. Para karyawan merasakan adanya ikatan yang sangat kuat antara karyawan dengan manajemen.

Sebagai gambaran dari hasil pra-studi tersebut tingkat turnover karyawan dalam tiga tahun terakhir di kantor pusat Jakarta dan cabang (Surabaya, Semarang, Denpasar, Makasar dan Padang) dipaparkan dalam tabel 1 berikut :

Tabel 1 Data Turnover Karyawan

\begin{tabular}{|c|c|c|c|c|}
\hline Tahun & $\begin{array}{c}\text { Jumlah } \\
\text { Karyawan } \\
\text { Masuk }\end{array}$ & $\begin{array}{c}\text { Jumlah } \\
\text { Karyawan } \\
\text { Keluar }\end{array}$ & $\begin{array}{c}\text { Total } \\
\text { Karyawan }\end{array}$ & $\begin{array}{c}\text { Turnover } \\
\text { Ratio }\end{array}$ \\
\hline 2010 & 25 & 6 & 381 & $1.57 \%$ \\
2011 & 11 & 5 & 387 & $1.29 \%$ \\
2012 & 7 & 2 & 392 & $0.59 \%$ \\
\hline
\end{tabular}


Dari tabel di atas terlihat bahwa rasio turn over karyawan pada periode tahun 2010 - 2012 adalah sebesar 1,57\%, 1,29\% dan $0,51 \%$ atau dapat dikategorikan rendah. Hal tersebut mengindikasikan bahwa karyawan masih ingin bertahan dan terikat dengan organisasi. Bagi penulis keinginan karyawan untuk tetap terikat dengan organisasi, sangatlah mengherankan. Hal tersebut disebabkan karena PT X bergerak di bidang jasa telekomunikasi yang berbasis teknologi informasi. Salah satu ciri dari perusahaan jasa telekomunikasi berbasis teknologi informasi adalah tingginya turnover karyawan. Karyawan dengan mudahnya keluar dari suatu perusahaan, karena mendapatkan penawaran yang lebih baik dari perusahaan lain. Sebuah survei yang dilakukan oleh perusahaan informasi kompensasi PayScale menunjukkan bahwa di antara perusahaan-perusahaan Fortune 500, perusahaan-perusahaan berbasis IT memiliki pekerja yang paling tidak loyal. Padahal, perusahaan-perusahaan ini memberikan kompensasi yang cukup besar bagi karyawannya (ekonomi.kompasiana.com tanggal 10 Oktober 2014). Namun kenyataannya, karyawan PT X merasakan hal yang sebaliknya. Para karyawan merasakan suatu kebahagiaan dapat bekerja di perusahaan ini. Para karyawan merasa mendapatkan perhatian yang memanusiakan dari pihak manajemen. Para karyawan tersebut menyebutkan bahwa manajemen tidak menganggap para karyawan sebagai bawahan atau pekerja semata, tetapi para karyawan diperlakukan sebagai mitra kerja yang sejajar dengan manajemen. Pihak manajemen tidak memberikan perlakuan yang berbeda terhadap karyawannya. Para karyawan merasa dirinya dimanusiakan, sehingga enggan untuk cari yang lain.

Perlakuan yang didapatkan oleh karyawan adalah cermin dari budaya organisasi yang salah satunya adalah kerja tim. Manajemen menganggap bahwa pekerjaan yang didapatkan perusahaan dari para kliennya, hanya dapat diselesaikan dengan cara kerja tim. Karenanya, manajemen 
memerlukan individu-individu pekerja yang loyal dan berkomitmen dengan pekerjaannya.

Robbins dan Judge (2009) menyatakan bahwa budaya organisasi yang kuat memiliki pengaruh yang cukup besar terhadap perilaku karyawan dan secara langsung mengurangi turn over. Dalam budaya yang kuat, nilai-nilai utama dalam organisasi dipegang teguh dan tertanam pada seluruh karyawannya. Budaya yang kuat akan membentuk kohesivitas, kesetiaan dan komitmen terhadap perusahaan.

Penulis menganggap bahwa para karyawan telah memperoleh apa yang disebut dengan well being, yaitu suatu keadaan di mana individu merasakan hal yang positif terhadap aspek penting dalam hidupnya, yang dalam hal ini adalah aspek kehidupan di tempat kerjanya. Keadaan positif yang dialami oleh para karyawan PT X menarik untuk diteliti. Apakah para karyawan PT X secara keseluruhan memang merasakan well being di tempat kerjanya? Faktor apa saja yang mempengaruhi tingkat well being para karyawan tersebut?

Pertanyaan-pertanyaan signifikan yang muncul tersebut perlu mendapat jawaban yang empirik, sehingga penelitian ini menjadi penting artinya untuk diteliti. Berdasarkan penjelasan yang telah diuraikan sebelumnya, penulis ingin mencoba mengaitkan beberapa variabel eksogen, yaitu kepuasan kerja, pengembangan karir dan job security dengan variabel endogen well being. 


\section{BAB II \\ TEORI TENTANG WELL-BEING \\ DAN JOB SECURITY}

\section{A. Well-being}

\section{Pengertian Well-being}

Well-being merupakan sebuah konsep yang berkaitan dengan perasaan individu mengenai aktivitas-aktivitasnya dalam kehidupan sehari-hari. Konsep ini seringkali dibahas dalam beberapa bidang, seperti kesehatan mental, kualitas hidup, dan gerontologi sosial (dalam Robinson, Shaver, \& Wrightsman, 1991). Ada perbedaan istilah maupun pengertian mengenai Psychological well-being. Perbedaan istilah ini telah berlangsung sejak sekitar tiga puluh tahun yang lalu. Robinson (1991) beserta rekan-rekannya menyebutkan beberapa istilah yang sering digunakan para ahli yaitu (subjective/perceived/sense of/psychological) well-being, subjective welfare, dan perceived life quality.

Selain perbedaan istilah yang digunakan, terdapat beberapa perbedaan pengertian dari para ahli. Secara umum, ada dua konteks atau pengertian tentang psychological well-being. Konteks yang pertama disampaikan oleh Bradburn (dalam Ryff, 1989) yang mengartikan psychological well-being sebagai kebahagiaan (happiness). Bradburn menggunakan kebahagiaan yang dirujuknya dari istilah eudamonia (kebahagiaan) Aristoteles. Eudamonia, bagi Aristoteles, adalah hal tertinggi yang dapat diraih oleh manusia. Konteks ini memandang well-being dari pendekatan eudaimonic (eudaimonic approach). Menurut pendekatan ini, psychological well-being didefinisikan sebagai pencapaian suatu kesenangan (pleasure) dan penghindaran terhadap penderitaan (pain). 
Konteks yang kedua mengartikan well-being sebagai kepuasan hidup (life satisfaction), makna hidup, dan realisasi diri (self realization). Konteks ini menggunakan pendekatan hedonic (hedonic approach). Dalam pendekatan ini, dijelaskan bahwa psychological well-being merupakan derajat seberapa jauh seseorang dapat berfungsi secara maksimal (Ryan \& Deci, 2001, dalam Keyes, Shmotkin \& Ryff, 2002). Beberapa peneliti lain menyatakan bahwa kepuasan hidup adalah pelengkap dari kebahagiaan hidup (Andrew \& McKennell; Andrew \& Withey; Bryan \& Veroff; Campbell, Converse \& Rodgers, 1976, dalam Ryff \& Keyes, 1995).

Secara lebih rinci, Diener (dalam Ratzlaff et al., 2000) menyebutkan tiga hal tentang konstruk subjective well-being, yaitu bahwa subjective well-being berada di dalam pengalaman individual, subjective well-being termasuk dalam pengukuran positif dan subjective well-being melibatkan penilaian menyeluruh terhadap semua aspek dalam kehidupan seseorang. Kemudian Diener dan Diener (1995, dalam Ratzlaff et al., 2000) mendefinisikan subjective wellbeing sebagai reaksi evaluatif seseorang atas kehidupannnya, baik dalam istilah kepuasan hidup (evaluasi kognitif) atau afektif (reaksi emosional).

Sedikit berbeda dengan pandangan di atas, Ryff (1995) mengatakan bahwa Psychological Well Being adalah suatu keadaan di mana individu dapat menerima kekuatan dan kelemahan diri apa adanya, memiliki hubungan yang positif dengan orang lain, mampu mengarahkan tingkah lakunya sendiri, mampu mengembangkan potensi diri secara berkelanjutan, mampu mengatur lingkungan, dan memiliki tujuan dalam hidupnya.

Warr (1999) membagi well-being individu menjadi dua konteks, yaitu perasaan individu yang berhubungan dengan pekerjaan (job specific well-being) dan perasaan individu yang berhubungan dengan konteks yang lebih luas pada setting situasi apapun (context-free well-being). Keduanya berada dalam konsep kesehatan mental yang lebih luas. Kahneman 
(1999) menjelaskan well-being sebagai suatu penilaian yang memunculkan perasaan senang atau tidak senang yang berhubungan dengan keadaan atau peristiwa dalam kehidupan individu.

Diener dan Lucas (1999) menyebutkan istilah subjective well-being sebagai suatu evaluasi atau penilaian seseorang atas kehidupannya. Penilaian ini meliputi penilaian kognitif terhadap kepuasan hidup dan penilaian afektif terhadap mood dan emosi. Seorang individu dikatakan mengalami subjective well-being yang tinggi apabila individu tersebut mengatakan bahwa kehidupannya memuaskan dan mengalami perasaan yang menyenangkan.

Well-being didefinisikan sebagai suatu perasaan yang menyenangkan yang berhubungan dengan seluruh keadaan atau peristiwa dalam kehidupan karyawan dalam pekerjaan.

\section{Aspek-aspek Well-being}

Jahoda (dalam Ryff, 1989) mengemukakan bahwa individu memiliki enam konsep kesehatan mental yang juga berarti kesejahteraan psikologis individu, yaitu menerima diri, hubungan positif dengan orang lain, otonomi, penguasaan lingkungan, tujuan dalam hidup dan perkembangan pribadi. Individu yang memiliki sikap positif terhadap dirinya sendiri mampu menerima segala kelebihan serta kekurangannya dengan tenang.

Pandangan di atas didukung oleh Allport (dalam Schultz, 1991) yang menyatakan bahwa sifat dari kepribadian yang sehat meliputi beberapa kualitas utama dari suatu penerimaan diri, maka dapat ditarik kesimpulan bahwa well-being mencakup beberapa aspek penerimaan diri,hubungan yang positif dengan orang lain, memiliki tujuan dalam hidupnya, mampu mengarahkan tingkah lakunya sendiri dan mampu mengembangkan potensi diri secara berkelanjutan. 
Aspek well being menurut Ryff (1989) yaitu aspek penerimaan diri (self acceptance), hubungan positif dengan individu lain (positive relation with others), otonomi (autonomy), penguasaan lingkungan (environmental mastery), tujuan hidup (purpose in life) dan pengembangan pribadi (personal growth), akan dijelaskan sebagai berikut :

a. Penerimaan Diri

Penerimaan diri adalah sikap positif terhadap diri sendiri, baik pada masa kini maupun masa lalu individu yang bersangkutan. Sikap positif yang diartikan sebagai sikap individu yang menerima segala aspek di dalam dirinya. Penerimaan diri merupakan kualitas yang penting bagi kehidupan manusia. Seorang individu yang tidak dewasa kepribadiannya akan bertindak layaknya anak kecil dalam menghadapi situasi yang tidak menyenangkan, dan akan bereaksi seperti mengeluh, menyalahkan orang lain, atau menyesali diri (self pity). Sebaliknya, seorang individu yang matang akan berusaha mengolah frustrasi yang dialami dan bukan melimpahkan kesalahan pada orang lain, tetapi justru berusaha untuk mereflesikan diri dan introspeksi diri. Seorang individu yang matang dapat menunggu waktu yang tepat dan atau untuk merencanakan tindakan dalam berhadapan dengan situasi dan rintangan yang ditemui. Jika perlu menyerah kalau situasi sudah tidak lagi memungkinkan.

b. Hubungan Positif dengan Individu Lain

Aspek hubungan positif dengan individu lain berkaitan dengan kemampuan menjalin hubungan antar pribadi yang hangat, memuaskan, saling mempercayai, memperhatikan kesejahteraan orang lain, mempunyai empati yang kuat, afeksi dan juga keintiman serta terdapat hubungan saling memberi dan menerima dalam interaksinya. 